\title{
Recorregut de recerca geològica i geoambiental per les comarques del Bages del Solsonès i del Berguedà: des de Cardona a Sorba, Linyà, Navès, La Vall D’Ora i Llinars de L'Aigua d'Ora
}

Josep Maria Mata-Perelló

Joaquim Sanz Balagué

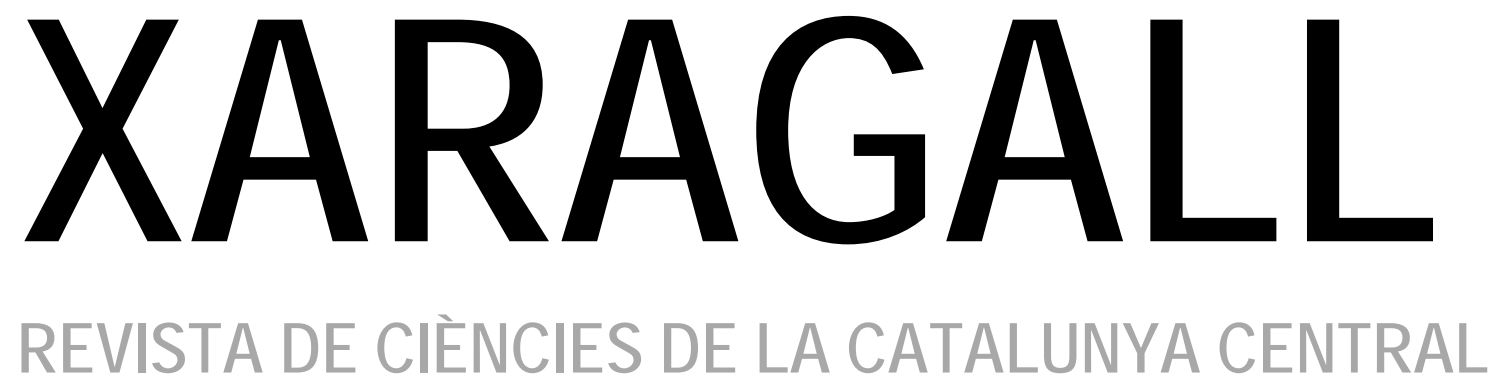

n. 3

MARÇ 2014 per als documents en línia; opcional per als altres). 


\title{
RECORREGUT DE RECERCA GEOLÒGICA I GEOAMBIENTAL PER LES COMARQUES DEL BAGES DEL SOLSONÈS I DEL BERGUEDÀ: DES DE CARDONA A SORBA, LINYÀ, NAVÉS, LA VALL D'ORA I LLINARS DE L'AIGUA D'ORA
}

\author{
Josep Maria Mata-Perelló \\ Museu de geologia Valentí Masachs, Escola Politècnica Superior d'Enginyeria de Manresa \\ (EPSEM), Universitat Politècnica de Catalunya · BarcelonaTech (UPC), 08272 Manresa, Spain
}

\section{Joaquim Sanz Balagué}

Departament d'Enginyeria Minera i Recursos Naturals (EMRN), Escola Politècnica Superior d'Enginyeria de Manresa (EPSEM), Universitat Politècnica de Catalunya - BarcelonaTech (UPC), 08272 Manresa, Spain

Paraules clau: Depressió geològica de l'Ebre; materials cenozoics; mines;

\begin{abstract}
Resum
Itinerari 23b realitzat al gener de 2013. En aquesta ocasió, el recorregut del present itinerari discorrerà per dues de les tres unitats geològiques que constitueixen Catalunya: concretament per la Depressió Geològica de I’Ebre, i pel Sistema Pirinenc.

Així, dintre de la primera, ho farà en bona part per un dels sectors que la constitueixen (MATAPERELLÓ, 1985): concretament per la seva Depressió Central, tot i que també recalarà pels sectors corresponents als Altiplans Septentrionals. Tot i així, ho farà pels indrets centrals de la primera, pels indrets on es troba replegada per diferents alineacions que la creuen d'Est a Oest. Aquests sectors poden situar-se dintre de la denominada Zona de I'Avant-país Plegat.

Per d'altra banda, dintre de la segona unitat geològica, pel Sistema Pirinenc, el recorregut del present itinerari discorrerà exclusivament pels sectors corresponent a la Zona Sudpirinenca, la seva sotsunitat més meridional.

Així, el recorregut començarà a Solsona, dintre de la comarca del Bages, per on no es farà cap aturada. Tot seguit entrarà breument a la comarca del Berguedà (per on no farem cap aturada), per entrar tot seguit a la comarca del Solsonès. La major part del recorregut es farà per aquesta comarca. Finalment, tornarà a entrar a la del Berguedà, per on finalitzarà. Test resum en idioma original de l'article.
\end{abstract}




\section{Objectius generals}

Els objectius fonamentals que es pretenen aconseguir en aquest itinerari, es poden concretar en els següents aspectes generals:

1. Observació i descripció dels materials terciaris eocènics i oligocènics de la Depressió Geològica de l'Ebre, que constitueixen el subsòl dels sectors meridionals de la comarca del Solsonès, pels indrets per on transcorre l'itinerari. En concret ens referirem als materials de la Formació Solsona (de caràcter eminentment sorrenc i gresenc) i als de la Formació Berga (constituïts exclusivament per trams de conglomerats).

2. Observació de les estructures locals d'aquests materials cenozoics acabats d'esmentar al llarg del recorregut de l'itinerari. Aquestes estructures es troben situades dintre de la Zona de l'Avant-país Plegat.

3. Observació dels materials mesozoics (del Triàsic, Juràssic i Cretàcic), els quals formen part del Mantell del Cadí i del Mantell Inferior del Pedraforca, ambdós de la Zona Sudpirinenca.

4. Visió de les relacions existents entre la Zona Sudpirenenca i la Depressió Geològica de I'Ebre (o més exactament entre la denominada Zona de l'Avant-país Plegat).

5. Observació de les discordances progressives existents entre els materials cenozoics de la Formació Berga. Aquestes es veuran per les immediacions de Sant Pere de Grau d’Escales, per sota de Busa, entre altres indrets.

6. Observació i reconeixement de les explotacions dels materials geològics, que es vagin trobant al llarg del recorregut de l'itinerari.

7. Observació dels impactes produïts sobre el Medi Ambient, i sobre el Medi Natural, per part de les explotacions abans esmentades

8. Observació dels diferents elements relacionats amb el Patrimoni Miner i amb el Patrimoni Geològic, que anirem trobant al llarg de tot el recorregut del present itinerari. Dintre d'aquest darrer, cal fer esment del relacionat amb les Discordances Progressives, de les que ja hem parlat anteriorment.

\section{Antecedents}

Existeixen diferents antecedents bibliogràfics parcials en relació al recorregut d'aquest itinerari. Així, entre aquests, farem esment dels següents: MASACHS et altri (1981), MATA-PERELLÓ $(1998,1999$ i 2010). Aquests itineraris coincideixen tant sols en els primers trams, amb el que ara presentem. També cal parlar del recent itinerari de MATA - PERELLÓ i SANJUAN OLIVER (2013), coincident puntualment en un dels darrers trams. Tot i així, cal dir que la major part del recorregut es totalment inèdit.

Per d'altra banda, i pel que fa a les mineralitzacions existents, a la comarca del Solsonès, ens remetin als treballs de mateix autor d'aquest itinerari, concretament a: MATA-PERELLÓ (1991 i 1994). I finalment, pel que correspon als treballs geològics de caràcter general, ens hem de referir necessàriament a les publicacions de: GUIMERÀ et altri (1992), i RIBA et altri (1976). I també als treballs de l'IGME (1975 i 1982). 
Tots aquests treballs acabats d'esmentar, figuren relacionats per ordre alfabètic a l'apartat de referències bibiografiques.

\section{Recorregut de l'itinerari}

El recorregut del present itinerari, s'inicia a la localitat bagenca de Cardona, per on no es farà cap aturada. Tot seguit es circularà per la carretera autonòmica $C-55$, fins a trobar el trencall de la carretera local que es dirigeix cap a Navès, passant breument pels voltants de Sorba, del terme berguedà de Montmajor. Per aquesta carretera aviat s'entrarà al Solsonès, arribant a la població de Linyà, des d'on es farà una fillola, per tal d'arribar a la Mina d'aram de Can Cogul, del terme solsonenc de Clariana del Cardener.

Després de retornar a Linyà, s'arribarà ben aviat a la població de Navès. A partir d'aquí es continuarà per la carretera autonòmica C - 26 (Tram de Solsona a Berga). Des d'aquí s'anirà cap a llevant, fins arribar al trencall de la carretereta que remunta el riu de I'Aigua d'Ora, passant per diverses localitats del terme de Navès (així com per alguns enclaus del terme berguedà de Montmajor). Per aquesta carretera s'arribarà a Sant Pere de Grau d'Escales. En aquest tram es realitzarà diverses aturades.

Tot seguit, caldrà anar cap a Llinars de l'Aigua d'Ora, anant pells límits entre el Solsonès i el Berguedà. Finalment s'arribarà a la carretera local LV - 4241 / BV 4241, fent-se un breu recorregut, fins a trobar la pista que segueix el traçat de I'antic ferrocarril miner de la Mina de Lignit del Coll d'Oreller). En aquest indret, dintre del Berguedà, finalitzarà el recorregut de I'itinerari, dintre del terme de Castellar del Riu, en el seu agregat de Llinars de I'Aigua d'Ora.

\section{Advertiment previ}

Com en altres recorreguts de RECERCA GEOLÒGICA I MINERALÒGICA ..., (i també dels de RECERCA GEOAMBIENTAL), si es disposa del temps suficient, poden efectuar-se els itineraris passant per totes les parades i filloles del mateix. En cas contrari, de no disposar d'aquest temps, recomanem prescindir de les anomenades PARADES - CONDICIONALS.

Com de costum, creiem oportú de recomanar, que alhora d'efectuar el recorregut de l'itinerari es cerqui la informació més àmplia possible sobre l'estat dels trams del recorregut a realitzar, tant per pistes forestals, com per carreteres en mal estat de conservació. En aquest recorregut, farem diversos trams per camins de terra en no gaire bon estat de conservació (com el de Sant Pere de Grau d’Escales a Llinars o com el d'aquesta població a la mina de lignit del Coll d'Oreller).

També, per altra banda, en qualsevol cas, i en tot moment (tant dintre del recorregut de l'itinerari, com fora d'ell), recomanem tenir el màxim respecte per al Medi Natural que ens envolta. 


\section{Descripció de l'itinerari}

Com ja es habitual, s'estructurarà en una sèrie d'estacions (parades o aturades), en les qual es faran descripcions geològiques o mineralògiques, segons s'escaigui.

En cada parada s'indicarà el número del mapa topogràfic a escala 1:50.000 on es troba I'indret. Per això, s'utilitzarà la cartografia editada per I'Instituto Geográfico y Catastral de España". En aquest cas, el recorregut de l'itinerari passarà per part dels dos següents fulls: 292 (també anomenat de Sant Llorenç de Morunys) i 330 (o de Cardona).

Així doncs, la relació general i ordenada, de les aturades que composen el recorregut d'aquest itinerari, és la següent:

\subsection{Parada 1. Mina d'Aram de Can Cogul, (terme municipal de Clariana de Cardener, comarca del Solsonès). (Full 330).}

El recorregut de l'itinerari el començarem a la localitat bagenca de Cardona, des d'on caldrà sortir cap al Nord, tot seguint la carretera autonòmica $C$-55. A uns $3^{\prime} 5 \mathrm{Km}$ de la sortida, ens caldrà creuar el riu Cardener, per tal de seguir per la carretereta local (sense numeració) que es dirigeix cap a Navès. Per aquesta carretera entrarem breument al Berguedà, prop de Sorba, del terme de Montmajor. I poc després entrarem al Solsonès, arribant a la petita localitat de Linyà. Aquí trobarem la carretera local BV - 3001. Per aquesta carretera iniciarem una fillola, anant cap a la pressa de l'embassament de Sant Ponç, abans d'arribar-hi, prop del trencall de Can Cogul (per l'esquerra), ens caldrà ascendir a peu per la dreta de la carretera, per tal de pujar fins a l'antiga Mina d'Aram de Can Cogul, on farem la present aturada. Aquest trencall, el trobarem a uns 100 metres abans d'arribar al de Can Cogul. Així, des de l'inici del recorregut haurem fet un trajecte d'uns $14 \mathrm{Km}$, aproximadament.

En aquest recorregut trobat afloraments dels nivells de gresos pertanyents inicialment a la Formació Artés, prop de Cardona, en transit lateral cap a la Formació Solsona. Així, inicialment haurem trobat nivells de gresos i de calcolutites de tonalitats rogencs, que poc a poc han passat a tindre tonalitats ocres, pròpies de la segona unitat litoestratigràfica esmentada. Aquesta es la que es troba a l'indret de la present aturada.

Molt sovint, entre aquests materials (a les dues formacions esmentades) es fan palesos els paleocanals. Aquests tenen uns materials més detrítics, fonamentalment amb gresos i fins i tot amb paleocanals. Aquests és fan molt més palesos a la Formació Solsona, com succeeix a l'indret de l'aturada.

Precisament en aquest lloc, a la base d'un d'aquests paleocanals, es fa ben palesa una mineralització cuprífera associada a "red-beds". Entre els minerals presents cal parlar de la MALAQUITA, força abundant. Tanmateix hi ha indicis d'ATZURITA. Aquesta mineralització es troba associada a la presència de matèria orgànica dintre de la base del paleocanal. Precisament, a l'esmentada base es troben uns nivells de tonalitat grisenca, la qual cosa denota la presència d'aquesta matèria orgànica. Inicialment, en els processos de reducció, es van forma els sulfurs de coure, que posteriorment es van oxidar en presencia dels carbonats del ciment dels paleocanals i de les calcolutites passant a carbonats de coure.

Cal fer esment de que cap a la primera meitat d'aquest segle, es va intentar l'explotació d'aquests materials cuprífers, tot i que en cap moment va gaudir de cap mena d'importància. (fotografia 1) 


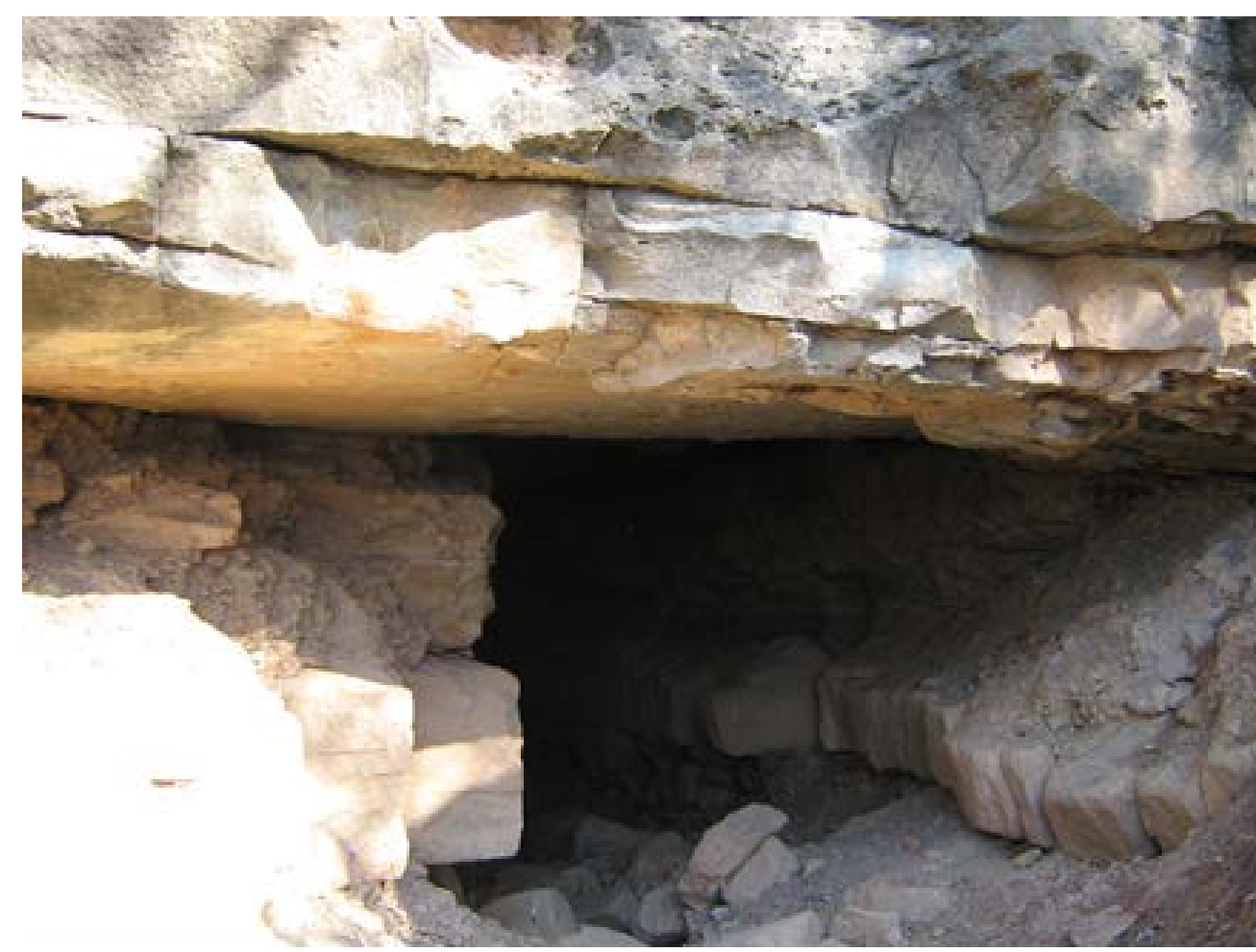

Fotografia 1. Boca de la Mina d'aram de Can Cogul, a la Formació Solsona.

A la part de sobre es veuen els gresos del paleocanal, lleugerament grisenc, com els materials de l'entrada de la mina.

Per d'altra banda, cal dir que aquesta mineralització es similar a l'existent per les immediacions de Riner, que va ésser explotada durant l'edat del Bronze.

\subsection{Parada 2 - Condicional. Carretera a Sant Pere de Grau D’Escales, trencall de Tentellatge, (la Vall d'Ora, terme municipal de Navès, comarca del Solsonès). (Full 282).}

Després de realitzar la parada anterior, cal retornar a la carretera local BV - 3001, per tal de retornar cap al poblet de Linyà, des d'on per la mateixa carretera s'anirà cap a Navès. A partir $d^{\prime}$ ara es continuarà cap a llevant per la carretera autonòmica $C-26$. Quasi en arribar al pont sobre el riu de la Vall d'Ora es trobarà una carretereta que es dirigeix cap el veïnat de la Vall d'Ora i posteriorment cap a Sant Pere de Grau d'Escales. En aquesta carretera, en arribar al trencall de Tentellatge, es pot fer una nova aturada, si s'escau, a uns $17^{\prime} 5 \mathrm{Km}$ de I'anteriorment realitzada.

En bona part d'aquest recorregut, hem anat remuntant el riu de la Vall d'Ora, que ja hem trobat a l'inici del recorregut de l'itinerari, pels voltants de les poblacions de Cardona i de Sorba. Aquest riu desemboca al Cardener, molt prop de la primera població acabada d’esmentar.

En aquest recorregut, hem anat trobant afloraments dels materials anteriorment esmentats. Aquests materials amb gresos i calcolutites ocres, pertanyen a la Formació Solsona, de I'Oligocè. Aquests són els materials que apareixen per l'indret de l'aturada. 


\subsection{Parada 3. Carretera a Sant Pere De Grau d’Escales, trencall de Busa, (La Vall d'Ora, Terme Municipal de Navès, Comarca del Solsonès). (Full 282).}

Des de la parada anterior, ens cal continuar per la carretereta local que va ascendint per la vall del riu de l'Aigua d'Ora. Més endavant, en arribar a la cruïlla d'on surt el trencall que es dirigeix cap a Busa, podem fer una nova aturada, a uns $4 \mathrm{Km}$ de l'anteriorment realitzada.

En aquest recorregut, hem continuat trobant afloraments dels materials esmentats a les aturades anteriors. Aquests materials són també els que apareixen a l'indret de la present aturada, situat per sota del faralló de Busa.

Des d'aquest indret, mirant cap al Nord es poden veure els relleus tabulars de la Serra de Busa. Així, es pot veure com tenen unes litologies eminentment detrítiques. Així, ho podem veure a la fotografia 3.

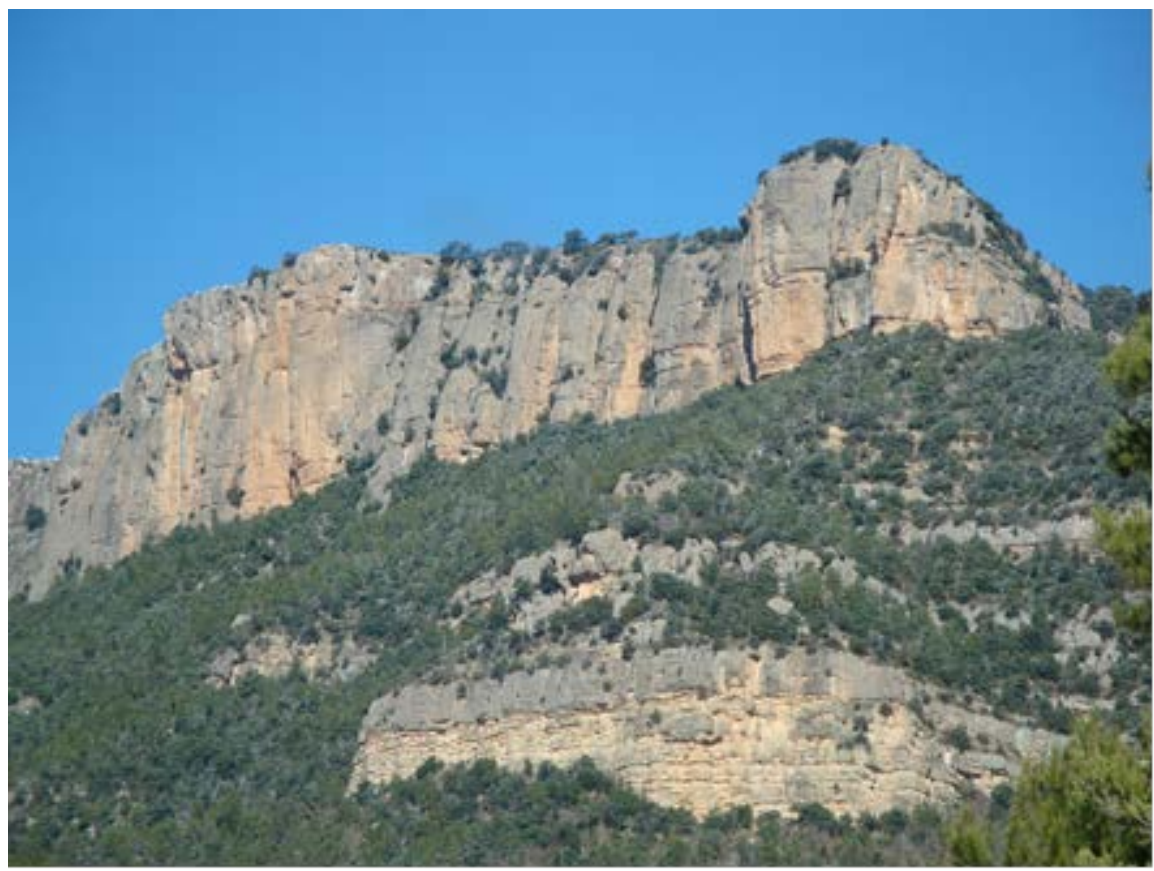

Fotografia 2. Relleus de la Serra de Busa, per sobre de la carretereta a Sant Pere de Grau d’Escales.

\subsection{Parada 4. Immediacions de Sant Pere de Grau d'Escales, (la Vall d'Ora, terme municipal de Navès, comarca del Solsonès). (full 292).}

Des de la parada anterior, cal fer un nou recorregut per la carretereta que ara s'encamina cap a Sant Pere de Grau d'Escales. Poc abans d'arribar-hi, haurem trobat, per la dreta, el camí que puja cap al poble de Llinars de I'Aigua d'Ora. EN arribar a Sant Pere, farem una nova aturada, després d'un recorregut aproximat d'uns $3 \mathrm{Km}$, des de la parada anteriorment efectuada.

En aquest trajecte, hem continuat trobant afloraments dels materials cenozoics dels que hem parlat a les aturades anteriors. Aquests materials són ara eminentment detrítics i pertanyen inicialment a la Formació Solsona; tot que cada cop són més detrítics i ja els podem incloure en el Complex de la Formació Berga. Tots aquests materials cenozoics son de l'Oligocè. En 
aquest indret, els materials es troben força verticalitzats, en contraposició amb els situats més amunt, a la Serra de Busa, que apareixen en una posició lleugerament horitzontal. Entre uns i altres es fa evident una clara discordança progressiva, que veurem millor a la propera aturada. (fotografies 3 i 4 ).

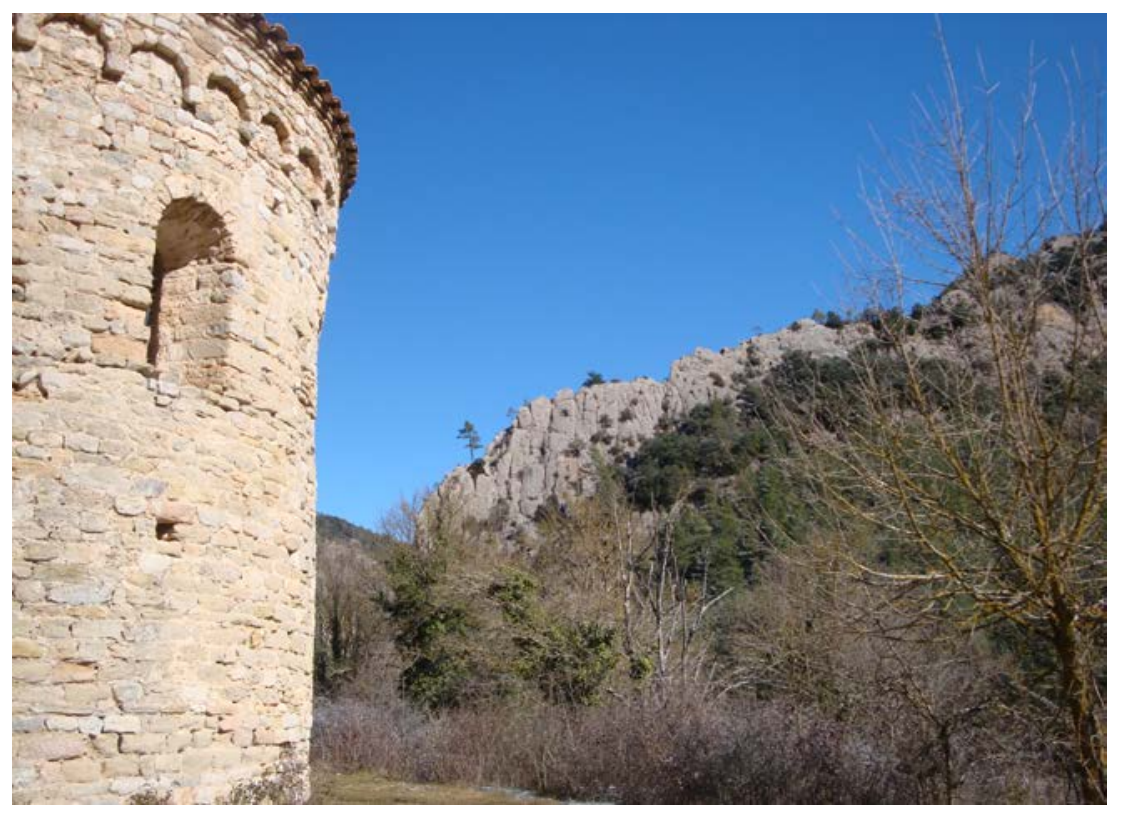

Fotografia 3. Materials detrítics oligocènics a la vora de Sant Pere de Grau d’Escales

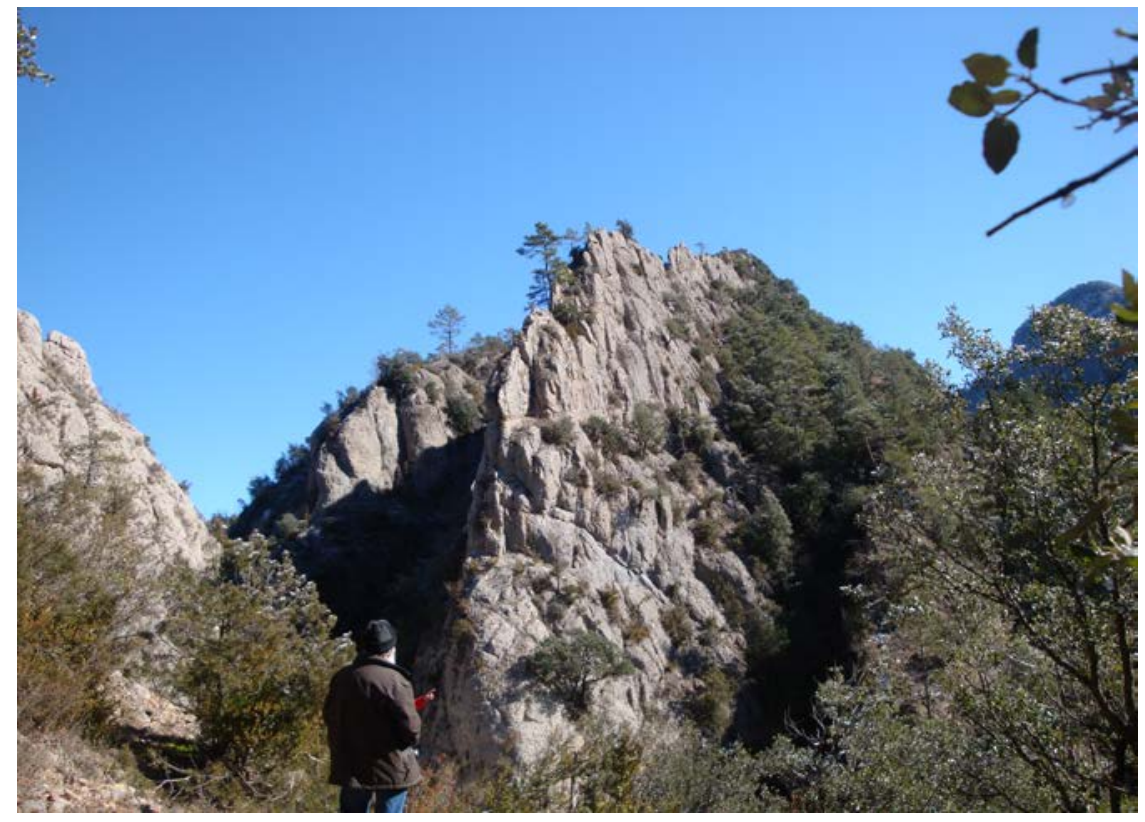

Fotografia 4. Un altre aspecte dels materials detrítics verticalitzats. 
Per d'altra banda, de l'indret de l'aturada es pot fer una magnífica observació de l'ermita de Sant Pere de Grau d'Escales. Aquesta ermita formava part d'un antic monestir benedictí, totalment desaparegut, excepte l'església.

\subsection{Parada 5. Mirador dels Presidents, Immediacions de Sant Pere de Grau d'Escales, (la Vall d'Ora, terme municipal de Navès, comarca del Solsonès). (Full 292)}

Des de la parada anterior, cal retrocedir lleugerament, fins trobar el camí que ascendeix cap a llogarret de Llinars de l'Aigua d'Ora. Es tracta d'un camí no gaire bo, inicialment molt ascendent, que en menys de $1 \mathrm{Km}$ arriba a l'indret del Mirador dels Presidents. En aquest lloc, situat per sobre de Sant Pere de Grau d'Escales, farem una nova aturada.

Des de l'indret de l'aturada es pot fer una magnífica observació de l'ermita de Sant Pere de Grau d'Escales, des de dalt.

En aquest breu recorregut, hem anat trobant els materials esmentats a l'aturada anterior, fonamentalment els materials detrítics del Complex Al-luvial Superior de Berga, que ara apareixen a la vora del camí. Es pot veure que predominen els materials fragmentats de calcàries mesozoics i paleozoiques, tot i que predominen les primeres.

Des d'aquest indret, mirant cap el SSW es pot veure clarament la Discordança Progressiva, que hem esmentat a l'aturada anterior. Així, en primer terme es veuen els nivells verticalitzats i en ocasió quasi amb cabussament invertit (formant part dels sectors més orientals de la Serra de Bastets); mentre que més amunt es veuen els materials detrítics en posició gairebé horitzontal, a la Serra de Busa. ( fotografies 5 i 6).

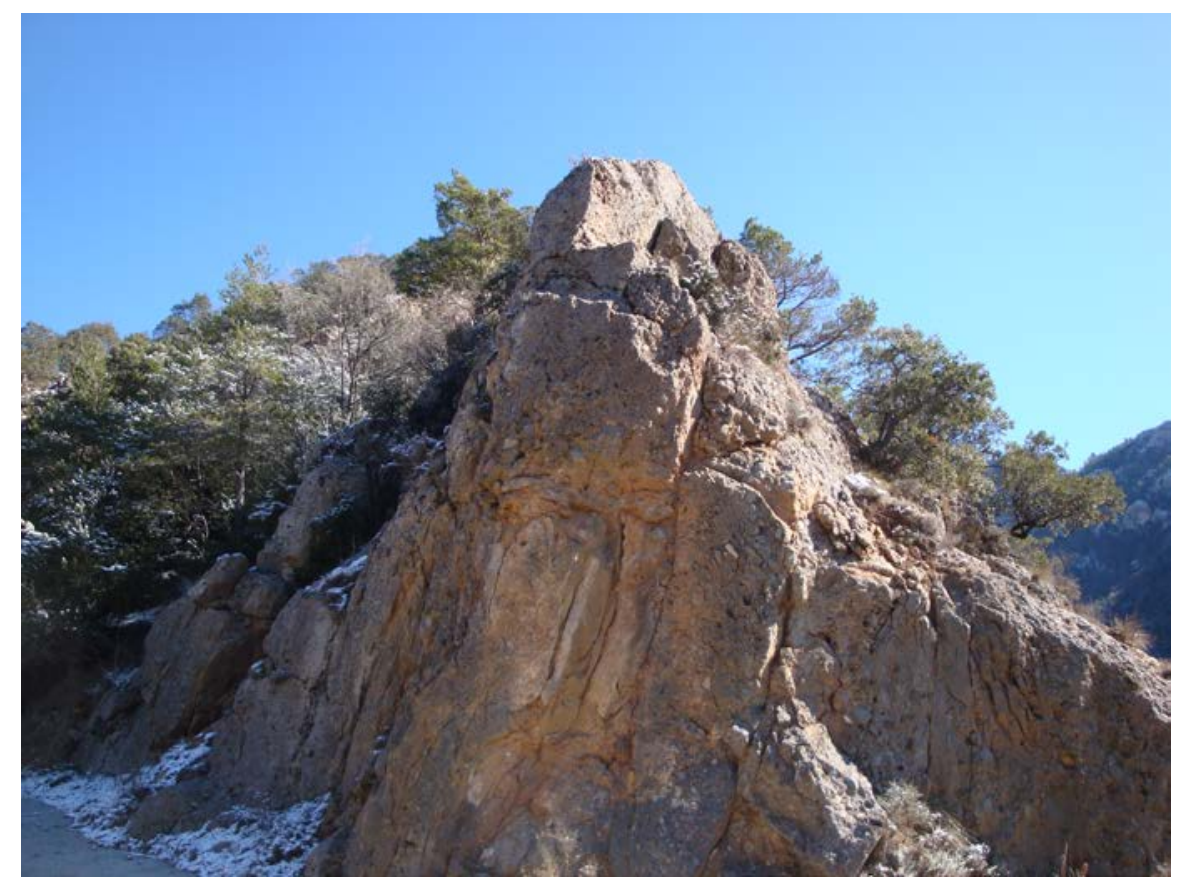

Fotografia 5. Un altre aspecte dels materials detrítics verticalitzats, pràcticament invertits. 


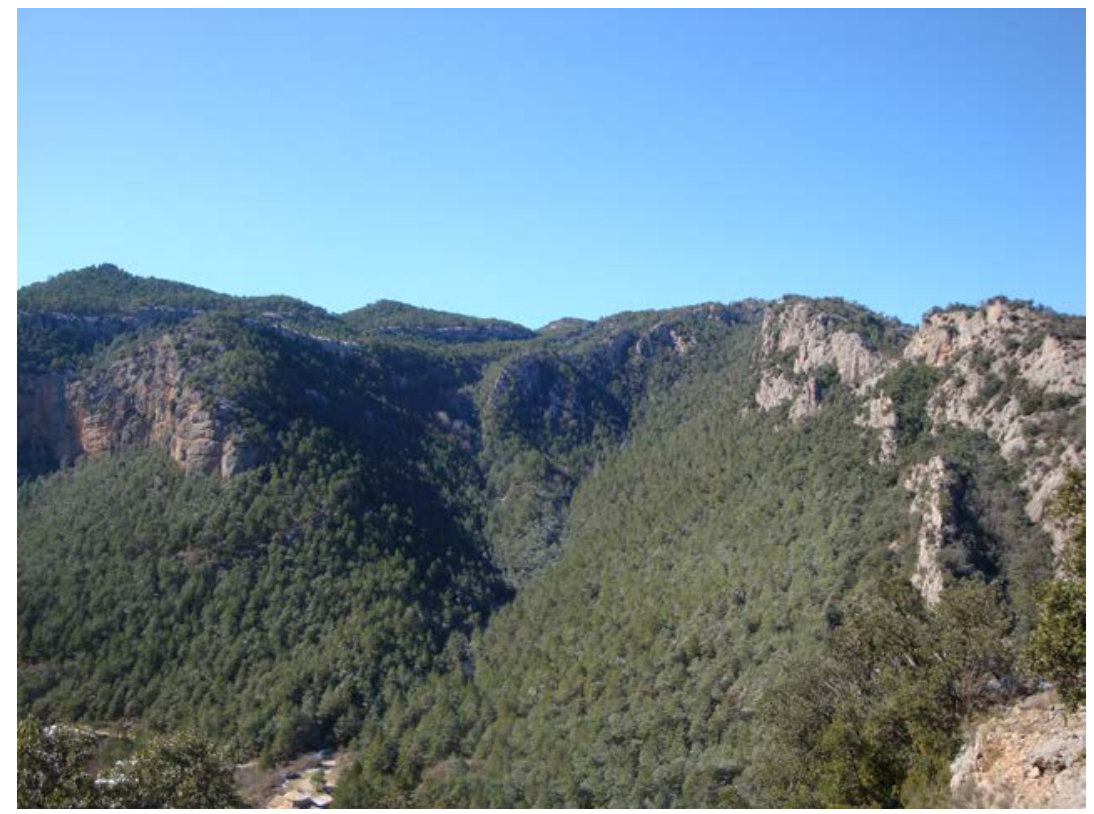

Fotografia 6. Un altre aspecte dels materials detrítics verticalitzats (a la dreta) i dels horitzontal (a l'esquerra), tot formant part de la Discordança Progressiva.

Per d'altra banda, mirant cap el Sud, es pot veure el congost obert pel riu de l'Aigua d'Ora, en travessar aquests materials detrítics, aigües avall de Sant Pere de Grau d’Escales (fotografia 7)

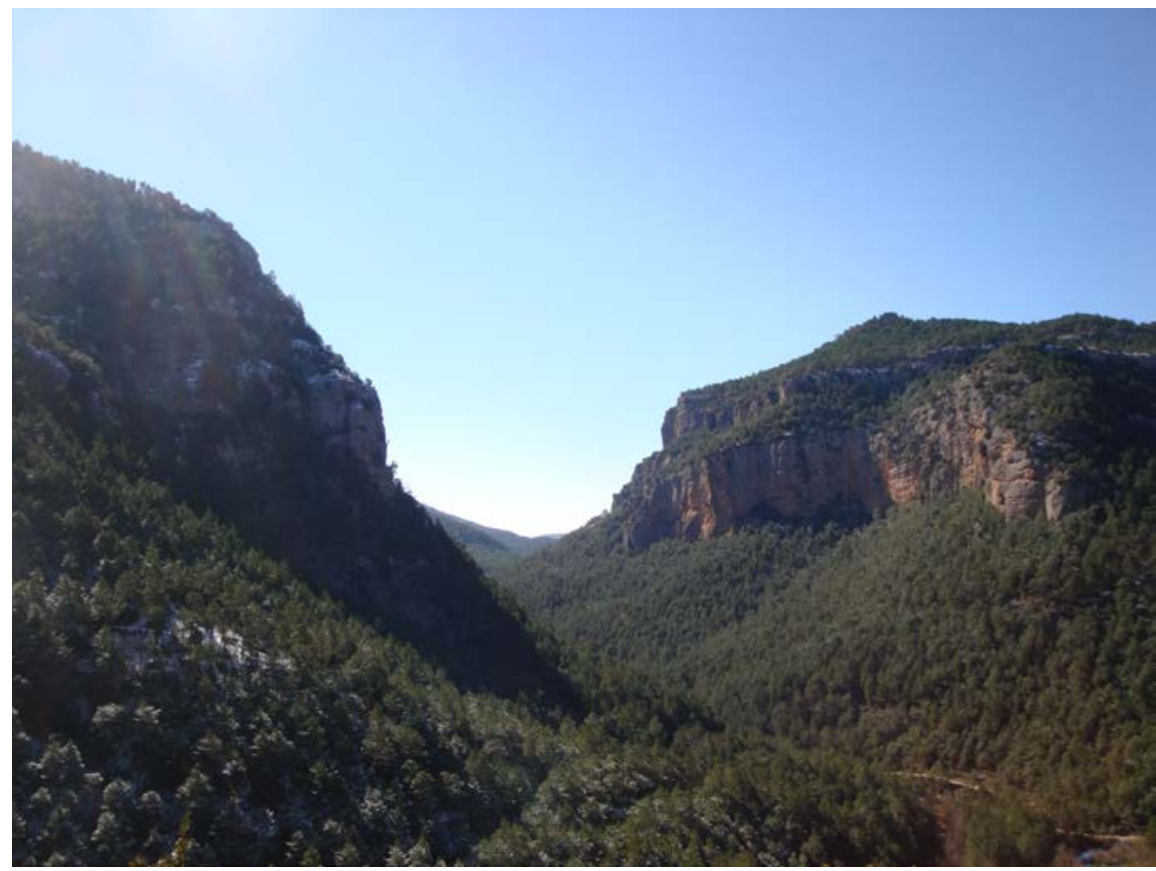

fotografia 7. Congost del riu de l'Aigua d'Ora, aigües avall de Sant Pere de grau d'escales 


\subsection{Parada 6. Explotació de guixos de I’Aigua d’Ora, (Sisquer, terme Municipal de Guixers, comarca del Solsonès). (Full 292).}

Després de fer l'aturada anterior, cal seguir pel camí de terra (generalment en no gaires bones condicions). Aquest camí va remuntant la vall del riu del Aigua d'Ora. En arribar prop del Molí de Bancells, el camí ja millora. Poc després arribarem a la carretera local LV - 4241. En arribar i trobar-la, cal traspassar l'esmentada carretera, per tal d'arribar a les actuals explotacions de guix. Aquí farem una nova aturada, a uns $4^{\prime} 5 \mathrm{Km}$ de la realitzada anteriorment i a menys de 0’ 5 del molí acabat d’esmentar.

En aquest recorregut, hem trobat inicialment els materials esmentats a l'aturada anterior. Tot i així, en arribar a l'indret de l'aturada s'han fet palesos uns afloraments de calcolutites grises, així com uns importants afloraments de guixos. Així, hem deixat enrere els nivells detrítics de l'Oligocè $i$ hem començat a trobar afloraments dels materials cenozoics de I'Eocè. Aquests darrers formen part del Mantell del Cadí. On ara ens trobem. És a dir: hem passat de la Depressió Geològica de l'Ebre al Sistema Pirinenc, havent ultrapassat la denominada Falla Sudpirinenca.

Precisament, aquí hi ha una gran explotació activa de guixos. Aquests guixos pertanyen a la Formació Campdevànol, de I'Eocè. L'explotació pertany a l'empresa KNAUFF i per entrar cal demanar la corresponent autorització. (fotografia 8).

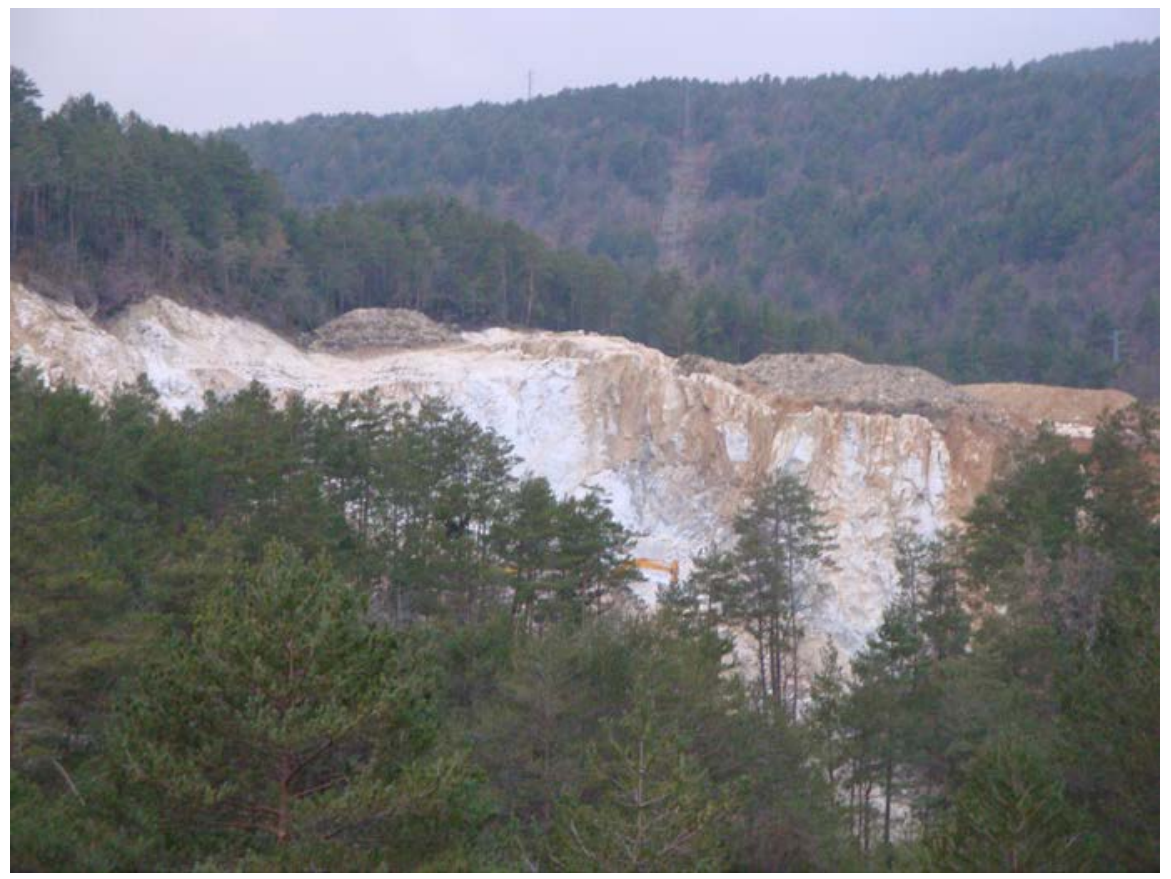

Fotografia 8. Explotació de guixos de les immediacions de Llinars 
Des d'aquest indret es pot fer una bona observació de l'explotació d'aquests guixos, mitjançant la mineria a Cel Obert. Així, es poden veure com s'efectuen els bancs d'explotació i els talussos.

\subsection{Parada 7. Ferrocarril miner del Coll d'Oreller, (Llinars de l'Aigua d'Ora, termes municipals de Capolat i de Castellar del Riu, comarca del Solsonès). (full 292).}

Després de realitzar l'aturada anterior, cal retornar cap a la carretera LV - 4241, passant ara de la comarca del Solsonès a la del Berguedà, al travessar la vall de I'Aigua de Llinars (un dels riuets que configuren el riu de l'Aigua de la Vall d'Ora). Al mateix temps, la carretera anterior es substituïda per la BV - 4241. Seguint lleugerament per aquesta via, arribarem aviat a la Serradora d'en Garriga i a la Cantina de Llinars. Poc abans, haurem trobat un mas, des d'on arribarem fàcilment a la plataforma d'un antic ferrocarril miner. En aquest indret, farem una nova aturada, a poc menys de $1^{\prime} 5 \mathrm{Km}$ de la parada anterior.

En aquest recorregut, haurem trobat afloraments dels materials esmentats a l'aturada anterior, els quals pertanyen als terrenys eocènics del Mantell del Cadí, on ara estem situats, dintre dels Pirineus. Aquests són també els materials que es situen a l'indret de la present aturada, tot $\mathrm{i}$ que sovint es troben recoberts per terrenys detrítics del Pleistocè i sobretot de l'Holocè, com succeeix aquí.

En aquest indret es fa clarament palesa l'existència de la plataforma d'un antic vial miner ferroviari. Per aquí baixava el lignit extret a les antigues minetes del Coll D'Oreller. A I'actualitat, aquest vial es utilitzar per un camí, que el segueix totalment. (fotografia 10)

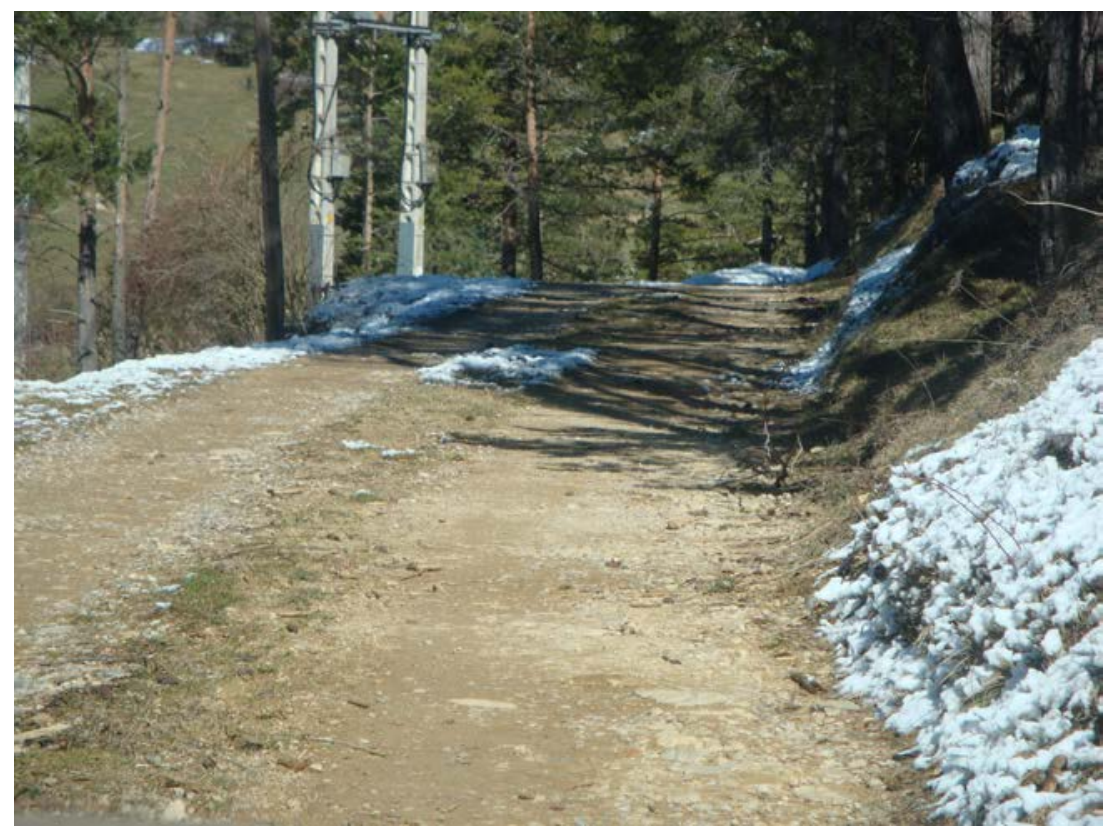

Fotografia 10 Plataforma del ferrocarril miner del Coll d'Oreller 


\subsection{Parada 8 - condicional. Mina de lignit del Coll d'Oreller, (Llinars de l'Aigua d'Ora, termes municipals de Capolat i de Castellar del Riu, comarca del Solsonès). (full 292).}

Després de realitzar I'aturada anterior, podem efectuar un nou recorregut cap el Nord, remuntant el vial de I'antic ferrocarril miner de la Mina de Lignit del Coll d'Oreller. Així, efectuarem un recorregut ascendent d'uns $4-5 \mathrm{Km}$, remuntant sempre el riu de l'Aigua de Llinars (riu de l'Aigua d'Ora). Així arribarem a l'antiga mineta, per on farem la darrera aturada d'aquest itinerari.

En aquest recorregut, hem trobat inicialment els materials cenozoics del Mantell del Cadí. Més amunt, hem començat a trobar afloraments dels materials mesozoics cretàcics del Mantell del Pedraforca Inferior. Aquest són els que es troben a l'indret de la present aturada

En aquest indret hi va haver-hi una petita explotació lignitífera. Aquesta es troba situada sobre un aflorament dels materials cretàcics del Garumnià; és a dir del Cretàcic Superior, que no arriben a aflorar. La boca de la mina es troba dintre d'un aflorament dels materials carbonatats del Cretàcic Mig. Tot i així, a l'actualitat la mina es troba totalment esfondrada. Aquesta es troba situada al límit entre el terme de Castellar del Riu (i més concretament del seu agregat de Llinars de l'Aigua d'Ora) amb el terme de Montmajor (en concret de la seva pertinença de Canals).

Per d'altra banda, aquesta mineta forma part de la Conca Lignitífera de I'Alt Berguedà, que ben prop d'aquí segueix per les antigues mines de Peguera, Fumanya i Fígols, cap el llevant d'on ara som.

Des d'aquest indret, es pot fer una bona observació de la Discordança Progressiva de la que hem parlat a algunes de les aturades anteriors. Així, mirant cap el SW, es poden veure les Serres de Bastets i de Busa, dibuixant clarament aquesta discordança, amb la Serra de Bastets (al Nord), amb els materials verticalitzats i la Serra de Busa (al Sud), amb els materials gairebé horitzontalitzats. (fotografia 11)

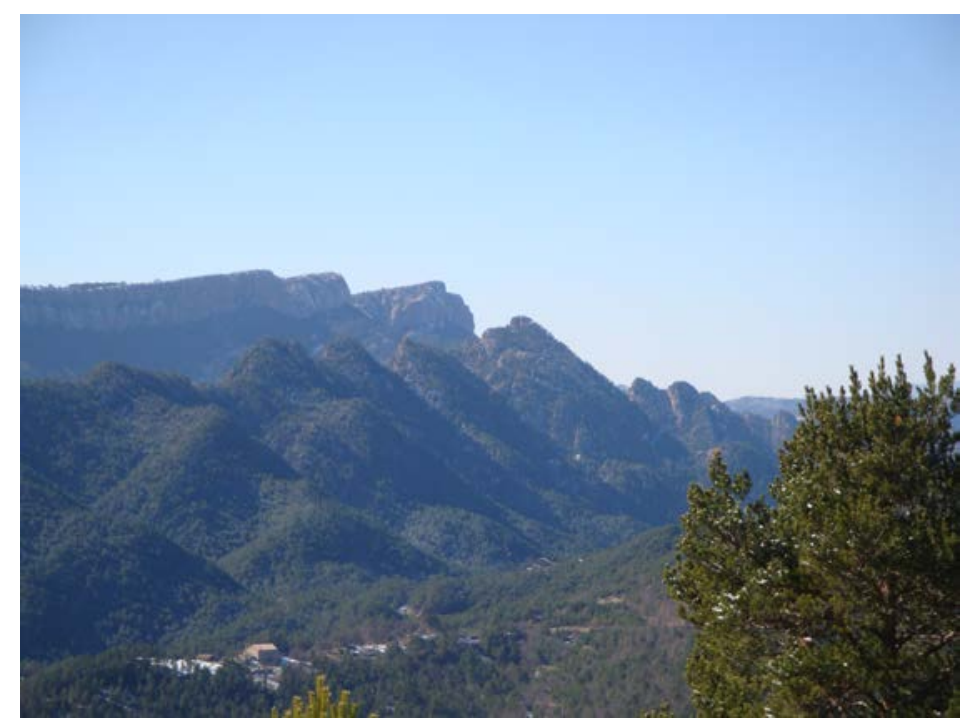

Fotografia 11. Discordança Progressiva entre la Serra de Bastets i la Serra de Busa, 
Per d'altra banda, des d'aquest indret, situat prop de l'antiga mineta del Coll d'Oreller, es pot veure, des de dalt, l'explotació guixera que hem trobat a la parada 6, d'aquest itinerari. (fotografia 12).

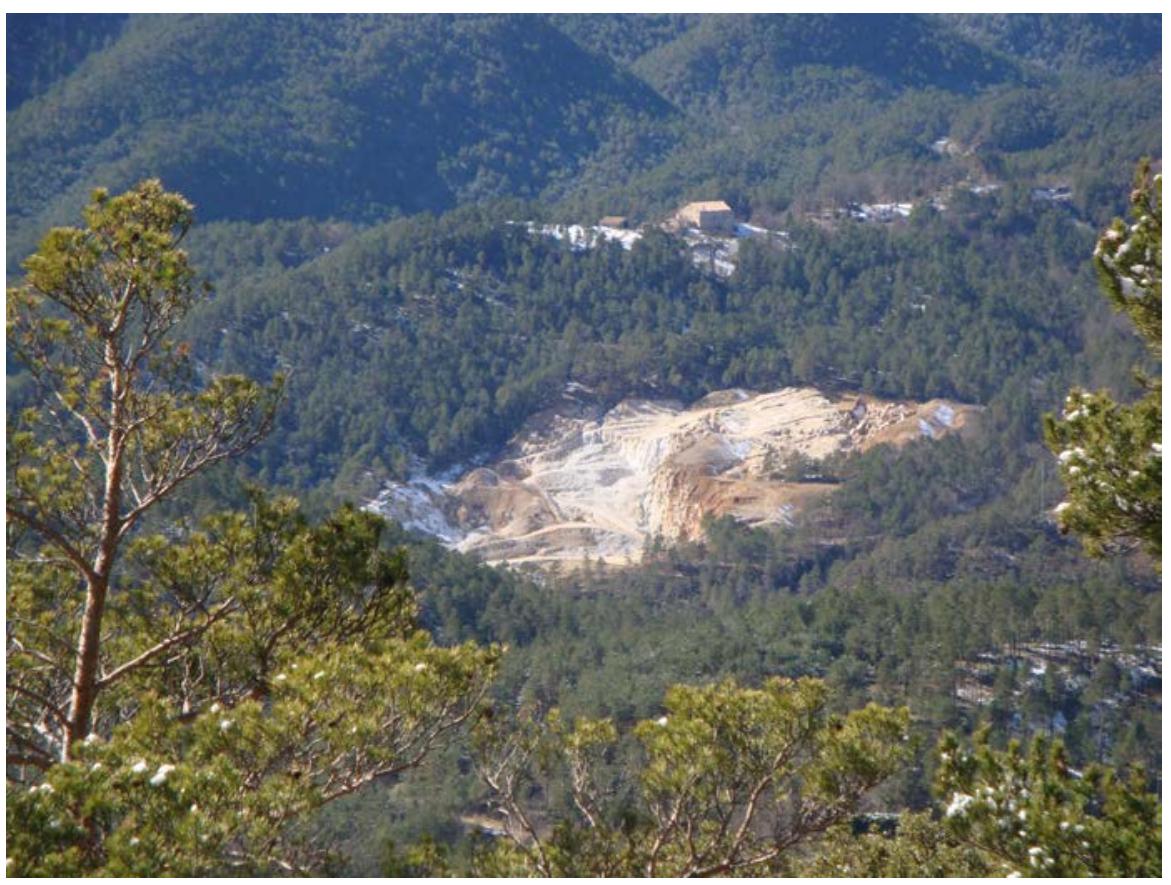

Fotografia 12. Explotació guixera de la PARADA 6, des del ferrocarril miner del Coll

En aquest indret finalitza el recorregut $d$ l'itinerari

\section{REFERÈNCIES BIBLIOGRÂFIQUES}

GUIMERÀ, J. et altri (1992).- Geologia (II), Història Natural dels Països Catalans, Vol. 2, 547 pag. Enciclopèdia catalana, S.A., Barcelona

IGME (1975).- Mapa Geológico de España a Escala 1:50.000 (2a Sèrie). Full i Memòria nº $\underline{330}$ (Cardona). Inst. Tecnológico y GeoMinero de España. Minist. Indus. Ener. Madrid

MASACHS, V. et altri (1981).- Itineraris geològics per Anoia, Bages, Berguedà i Solsonès. Pub. Caixa d'Estalvis de Manresa, 205 pag. Manresa

MATA-PERELLÓ, J.M. (1984).- Depressió Central o Depressió de I’Ebre, Revista Dovella, nº 36, pp 85-89. Manresa

MATA-PERELLÓ, J.M. (1991b).- Els Minerals de Catalunya. Arxius de la Secció de Ciències, $t$. XCIII. 442 pàgines, Institut d'Estudis Catalans. Barcelona 
MATA-PERELLÓ, J.M. (1994).- Inventari Mineralògic de la comarca del Solsonès. Xaragall, 14, 30 pàgines. Manresa

MATA-PERELLÓ, J.M. (1998).- Recorregut de recerca geològica i mineralògica per les comarques del Bages i del Solsonès: des de Súria a Cardona i a Solsona. Inèdit 12 pag. Manresa

MATA-PERELLÓ, J.M. (1999).- Recerca geològica i mineralògica per les comarques del Bages i del Berguedà, des de Cardona al Coll de Port. Inèdit. 15 pàg. Manresa

MATA-PERELLÓ, J.M. (2010).- Recorregut de recerca geològica i minera per les comarques del Bages i del Solsonès: des de Callús i Sant Mateu de Bages cap a Súria, Cardona i Solsona. Inèdit. 12 pàgines. Manresà

MATA-PERELLÓ, J.M. i SANJUAN OLIVER, J. (2013).- Recerca geològica i geoambiental per les comarques del Berguedà i del Solsonès: des de Berga i el Santuari de Queralt a Llinars, Guixers i a Sant Llorenç de Morunys. 16 pàgines. Manresa

RIBA ARDERIU, O. (1967).- Resultados de un estudio sobre el terciário continental de la parte Este de la Depresión Central Catalana. Acta Geológica Hispánica, t.. 2, Vol.1, pp. 3-8. Barcelona

RIBA ARDERIU, O. Et altri. (1976).- Geografía física dels Països Catalans. Edit Ketres, 205 pàgines. Barcelona 